\title{
Kentsel Mekânda Kadınların Yaşadığı Suç Korkusu Üzerine Bir Araştırma*
}

\section{A Study on the Fear of Crime in Women in the Urban Area}

\author{
Kadir TEMURÇİN ${ }^{1}$ (D), Mahinur KILIÇ${ }^{1}$ (D), Yolcu ALDIRMAZ ${ }^{1}$ (D) \\ ${ }^{1}$ Süleyman Demirel Üniversitesi, Fen Edebiyat Fakültesi, Coğrafya Bölümü, Isparta, Türkiye
}

ORCID: K.T. 0000-0002-8726-3756; M.K.0000-0002-9991-6128; Y.A. 0000-0001-8669-192X

\section{öz}

Kentsel mekânda giderek daha fazla görünür hale gelen suç ve onun sonuçları, bireyin dünyasında belirli bir tedirginliğe yol açarak bir korku hissinin oluşmasına neden olmaktadır. Birçok kişiyi olumsuz yönde etkileyen korku deneyimleri, günlük rutinlerde birtakım değişikliklere yol açmaktadır. Bu açıdan suç korkusu toplumun her kesimini farklı şekillerde etkilemekle birlikte, özellikle kadınlarda daha belirgin gözlemlenmekte ve sonuçları kişilerin yaşantısında daha görünür önlemlere/tepkilere sebep olmaktadır. Bu korku durumunun nedeni her ne kadar toplumsal çözümlemelerle analiz edilse de arka planda ilgili kişilerin yaşadıkları fiziki çevrenin de etkili olduğu düşünülmektedir. Bu çalışmada da, Isparta şehrinin bir mahallesi olan Bağlar'da kadınların yaşadığı suç korkuları mekânsallıklarıyla birlikte araştırılmıştır. Araştırmada, nitel araştırma desenlerinden durum çalışması seçilmiş, tesadüfi örnekleme yöntemiyle görüşmeler yapılmış, görüşmede elde edilen bulgular şehrin fiziksel unsurlarıyla birlikte değerlendirilmiştir. Çalışmanın bulguları ise iki farklı çerçevede sunulmuştur. İlki mekânsal düzensizliklerin suç korkusunun oluşumunda ya da korku hissinin artmasında etkili olduğuna, ikincisinde ise sosyal meseleler ve sosyal çevredeki bozulmaların suç korkusunun toplumsal düzeyde yorumlanmasında önemli bir role sahip olduğuna vurgu yapmaktadır. Dolayısıyla kadınların yaşadıkları korku veya kendilerini güvende hissetme duygusu mahallenin gerek fiziki gerekse de sosyal görünümüyle açıklanmıştır.

Anahtar kelimeler: Suç, suç korkusu, kentsel mekân

\section{ABSTRACT}

Crime and its consequences, which are becoming visible in the urban space, generate apprehension and a sense of fear in the individual's world. Fear of crime affects all segments of society in different ways, but it's observed especially in women and its results cause more visible measures/reactions in people's lives. The reason for this fear situation is analysed by social analysis, the physical environment in which the people live in the background is also thought to be effective. The fears of crime experienced by women in Bağlar, a neighbourhood of the city of Isparta, were investigated together with their spatiality. A case study was selected from the qualitative research patterns, interviews were conducted with the random sampling method, and the findings obtained in the interview were evaluated together with the physical elements of the city. The first emphasizes that spatial irregularities are effective in the formation of fear of crime or the feeling of fear, and in the second, social issues and deterioration in the social environment have an important role in interpreting the fear of crime at the social level. Feelings of fear or safety in women is explained with both the physical and the social appearance of the neighbourhood.

Keywords: Crime, fear of crime, urban space

*Bu çalışma 20-22 Haziran 2019 tarihinde İstanbul'da gerçekleştirilen 1. Uluslararası İstanbul Coğrafya Kongresi'nde sunulan ve özet bildiriler kitabında yer alan aynı başlıklı bildirinin genişletilmesiyle oluşturulmuştur.

Başvuru/Submitted: 07.02.2020 • Revizyon Talebi/Revision Requested: 21.04.2020 • Son Revizyon/Last Revision Received: 04.06.2020 • Kabul/Accepted: 08.06.2020 - Online Yayın/Published Online: 17.12.2020

Sorumlu yazar/Corresponding author: Mahinur KILIÇ / mahinurkilic@sdu.edu.tr

Atıf/Citation: Temurcin, K., Kilic, M., \& Aldirmaz, Y. (2020). Kentsel mekânda kadınların yaşadığı suç korkusu üzerine bir araştırma. Cografya Dergisi, 41, $45-60$. https://doi.org/10.26650/JGEOG2020-0003 


\section{EXTENDED ABSTRACT}

Feeling that they are in an unsafe environment, experiencing fear or anxiety, or facing the fear of being a victim of a crime can leave deep scars on individuals. Fear of crime which is also defined as a social problem in many literary works, is among the major problems that have a negative impact on both way and quality of life. In particular, the fear of being a victim of a crime further reinforces the need for protection in terms of security. A crime incident happening or occurring anywhere concerns people and forces them to take various measures and to deal with such situations. Women can feel more fear in situations where the possibility of encountering danger is a likely possibility at any given moment. The fact that women are more fearful than other individuals is closely related to their ability to defend themselves. Therefore, women try to protect themselves with certain avoidance behaviors aimed at reducing the risk of victimization. However, some events that occur while walking in urban areas, common public spaces or even on the street limit women's mobility and also affect daily routines significantly.

In recent studies in the context of gender, fear situations have been investigated (Gilchrist, vd., 1998, Condon, vd., 2007, Dobbs, vd., 2009, Hilinski, vd., 2011, Tandoğan ve İlhan, 2016). The focus of this study is the fear of crime in urban areas experienced by women, who feel more vulnerable in daily life. Therefore, this study draws attention to the spatial meaning of the fear of crime experienced by women by establishing a connection between both concepts, not only in terms of space or being human.

Accordingly, the Bağlar Neighbourhood, which is a neighborhood of the city of Isparta, was chosen as a sample and, in particular, the physical and social structure of the neighborhood was taken into consideration when choosing this place. Factors that cause fear of crime in women are interpreted based on the Social Control Perspective, one of the approaches to fear of crime. In this approach, various factors that point to social and physical disorder create favorable environments that also lead to crime. Therefore, the deterioration in the social and physical environment, turmoil, chaos and social anxiety cause more insecurity and anxiety in women. Based on this approach, efforts were made to reveal the uneasiness, anxiety, fear and negative events occurring in the neighborhood through random interviews. Fear or anxiety situations, especially from people associated with the neighborhood or a crime, have been addressed based on the women's own experiences. The intended scope of the study was to examine the extent to which the fear experienced by women affects their lives and daily activities. In this respect, women were asked various questions about why they preferred this neighborhood, their relationship with neighborhood residents, what they are most anxious about, and whether they are safe in the neighborhood.

As a result of the findings obtained, the fears experienced by women were classified as headings and evaluated with the different socio-spatial patterns of the neighborhood. Events experienced in different categories and fear situations were interpreted. The subcategories that emerged revealed that women were exposed to verbal or visual harassment on the street in various circumstances and that there were time periods which made them apprehensive and limited their habits. Of course, these disturbing behaviors can threaten women's personal safety and force the space to be used in a limited way. Another situation that it is manifested is that one of the areas where women do not feel completely secure outside the public domain is the houses they live in. It was emphasized that theft events occurring in the neighborhood from time to time were effective in making them apprehensive and that they had to develop various measures especially for this likelihood. It is also important that the apartments built throughout the neighborhood and the residents living there differ. The fact that residents of the apartments do not know each other and it is not known whether someone who enters an apartment intends to commit theft or something else causes considerable anxiety. Likewise, the existence of different ethnic identities in old, neglected or low cost housing or apartments has revealed that women are afraid of foreign nationals. Considering that these individuals in particular may be a source of danger, a bias has developed against them and measures have been developed to counter the likelihood of harm. Furthermore, women in the neighborhood emphasized that they were more worried and fearful for their relatives and especially their children. Due to certain events in the neighborhood, families keep their children under control as much as possible and they are sensitive in this regard.

Indeed, the findings show that while some events in the neighborhood have contributed to the overall negativity about the neighborhood, the physical and social disorder in the neighborhood can also be shown as a source of fear experienced in the neighborhood. 


\section{GÍRIŞ}

Suç korkusu uzun yıllar bilinmesine rağmen ancak yakın zamanda önemli bir sosyal bilim kavramı olarak kabul görmüştür (Jarrett-Luck, 2015). Avrupa'da suç korkusu terimi 1960'lardan önce bilinmiyorken, İngiltere'de 1982'de Britanya Suç Araştırması'nın bir parçası olarak resmi anlamda araştırılmaya başlanmıştır (Meško, Fallshore, Muratbegović ve Fields, 2008). İlk araştırmacılar, özellikle suç korkusunun ne olduğu/ne olmadığı ile ilgilenmiş ve daha çok suç korkusunun işlevselleştirilmesine ve kavramsallaştırılmasına odaklanmışlardır (Rader, 2017). Suç korkusu, endişe ile dişa vurulan duygusal bir tepki (Garofalo, 1981), suçla ilgili geliştirilen semboller dizisi (Ferraro ve LaGrange, 1987), sosyal ve ekonomik güvencesizlik, öz kimliğin izolasyonu ve kırılganlığı (Bernard, 1992) veya günümüz şehirlerinde büyüyen bir sosyal sorun, politika konusu ve sosyal stresör (Pacione, 2003) olarak nitelendirilmiştir. Kısaca yıllardır yapılan araştırmalara karşın suç korkusunun tanımı tam anlamıyla netleşememiş, ancak süreç içerisinde çeşitli duygusal durumlar, tutumlar, kaygı, yabancı korkusu v.b. algılarla bu kavram ifade edilmeye çalışılmıştır (Warr, 2000).

Suç korkusuna yönelik geliştirilen yaygın kanı ise, derin bir kişisel kaygı duygusunun ötesinde bir sonuç doğurduğu farkındalığının artması yönündedir. 1980'lere kadar daha az dikkat çeken suç korkusu, artık suçtan daha büyük bir problem olarak düşünülmeye başlamıştır (Hale, 1996). Günümüzde ise kriminoloji alanında çoğunlukla çalışılan konu olmasının yanı sıra (Farrall, Bannister, Ditton ve Gilchrist, 2000) suç ve sonuçları hakkındaki algıların anlaşılması için çeşitli incelemeler yapılmaktadır (Lee, 2007). Bu çalışmalarda genel olarak güvenlik ve suç korkusunun birbiriyle nasıl ilişkili olduğu (Balkin, 1979), suç korkusunun neden ve sonuçları (Garofalo, 1981), suç korkusunu açılamaya ve ölçmeye yönelik bir dizi model önerileri (Ferraro ve LaGrange, 1987), korkuyu azaltmaya yönelik geliştirilen bir takım politikalar (Box, Hale ve Andrews, 1988), kentsel alanlarda yaşanan suç korkusu (Covington ve Taylor, 1991), insanların suç mağduriyeti riskini nasıl yorumladıklarını ve kimin suçtan korkma olasılığının yüksek olduğu (Ferraro, 1995), endişe çağında ortaya çıkan suç korkusu (Hollway ve Jefferson, 1997), suç korkusunun sosyal psikolojik boyutu (Farrall, vd., 2000), suç korkusundaki güvenlik açığının psikolojik açıdan değerlendirilmesi (Jackson, 2009), sosyal, kültürel ve teknolojik değişimler ışığında suç korkusu konseptinin yeniden ele alınmasına dair (Jarrett-Luck, 2015) araştırmalar dikkat çekmektedir.

Yine yakın tarihli araştırmalarda artık belirli gruplarda veya sınıflarda suç korkusu analiz edilmeye başlanmıştır. Cinsiyet bağlamında korku durumlarının ele alındığı çalışmalar da bunlardan birisidir. Özellikle suçtan kaçınmak için atılan adımlarla, suçun günlük yaşamdaki genel etkisi düşünülerek erkeklerle kadınların suç korkuları arasında çarpıcı benzerlikler olduğunu ortaya koyan çalışmalar olmakla birlikte (Gilchrist, vd., 1998), suç korkusu hakkında toplumsal cinsiyet temelli farklılaşmaların olduğunu gösteren ve kadınların bu korkuyu daha yoğun yaşadıklarını ortaya koyan çalışmalar da vardır.

Özellikle kadınların güvenliği, mağduriyet deneyimleri ve kadınların kamusal hareketliliği arasındaki ilişki (Condon, Lieber ve Maillochon, 2007), erkeklere oranla daha yüksek mağduriyet korkusu yaşayan kadınlarda, tecavüz korkularının kadın ve erkekler üzerindeki etkisi (Dobbs, Waid ve Shelley, 2009), kadınların sürekli olarak erkeklerden daha yüksek suç korkusu yaşadığı ve kadınların neden bu kadar korkulu oldukları (Hilinski, Neeson ve Andrews, 2011) ve kadınların kamusal açık alanlarda yaşadıkları suç korkusunun nedenleri (Tandoğan ve İlhan, 2016) tartışılmıştır. Aynı zamanda kadınların rapor ettikleri suç korku düzeylerinin, erkekler tarafindan bildirilen suç korku seviyesinden iki-üç kat daha yüksek olduğu birçok çalışmada tespit edilmiştir (Reid ve Konrad, 2004). Savunmasız olarak değerlendirilen kadınların (ve ayrıca yaşlı ve yoksulların) suç hakkında daha fazla endişeli olduğu da belirtilmektedir (Jackson, 2009).

Böyle bir farklılık suç korkusunun feminist coğrafyada da yer edinmesine neden olmuş ve kadınların korku durumları mekânsal veya alansal nedenlerle ya da düşüncelerle desteklenmiştir. Örneğin Valentine, kadınların suç korkularının mekânsallığına dikkat çekerek bunu cinsiyet eşitşizliği ile ilişkilendirmiştir. Özellikle kadınların erkek şiddet korkusu ile mekân algıları ve kullanımı arasındaki ilişkiyi incelemiş̧ir. Kamusal alanın farklı zamanlarda farklı gruplar tarafindan nasıl işgal edildiğine ve kontrol edildiğine dikkat çekmiștir (Valentine, 1989). Bu düşüncesini bir adım daha öteye taşıyan Valentine, insanların mekâna nasıl egemen olduğunu ve bu egemenliğin nasıl kırılabileceğini araştırmıştır. Bu korkuyu ortadan kaldırmak veya azaltmak için kamusal alanların tasarımı için alınan önlemlerin kadınların kendilerini daha fazla güvende hissetmelerini sağlayacağını ifade etmiştir (Valentine, 1990). Kadınların korkusunun erkeklerin korkusundan önemli ölçüde farklı olduğunu belirten Pain (1991) ise, kadınların kamusal alanda olduklarında daha çok korktuğunu vurgulamaktadır. Çünkü bu suç korkusu birçok kadının firsatlarını, davranışlarını, mekânsal algılarını ve günlük rutinlerini sinırlandırmaktadır. Koskela (1999), ise kadınların korkularının doğal olarak değil, toplumsal olarak üretildiğini ve mekânsal hale getirildiğini belirtmektedir. Özellikle kadınların korku ve hoșnutsuzluk 
duyguları, bu mekânsal düzenlemelerin cinsiyet ve diğer alanlarla ilişkili olarak şekillenmesine ve tanımlanmasına yardımcı olduğunu vurgulamaktadır.

Suç korkusu üzerine yapılan çalışmaların eğilimlerine yönelik çizilen çerçevenin de gösterdiği üzere, suç korkusu çoğunlukla toplumsal bir olgu olarak görülmüş, nedenleri ise yine çoğunlukla sosyal meselelerde aranmıştır. Yakın tarihli ve nispeten az sayıda olmak üzere bazı çalışmalar suç gibi suç korkusunun da mekânsal olarak gömülü olduğunu ileri sürmektedir (Temurçin, 2018). Bu kapsamda suç korkusunun hem toplumsal hem de mekânsal nedenlerinin tespit edilmesi daha bütünlüklü bir değerlendirme için önem arz etmektedir. Bu çalışmada böyle bir yaklaşımla Isparta şehrinde suç korkusunun göreli olarak yüksek düzeyde gözlemlendiği mahallelerden biri olan Bağlar'da suç korkusunun içeriğini, boyutlarını, nedenlerini, sonuçlarını hem toplumsal hem de mekânsal yönleriyle ele almayı amaçlanmaktadır. Çalışma üç bölüm halinde organize edilmiş olup ilk kısımda suç korkusunu çözümlemeye yönelik geliştirilen teorik yaklaşımlardan bahsedilmiştir. Burada özellikle sosyal kontrol perspektifine vurgu yapılmıştır. İlgili teori suç korkusunu hem toplumsal hem de mekânsal (fiziki çevre) unsurlarını içerecek şekilde ele almasıyla diğer yaklaşımlardan ayrılmaktadır. İkinci kısımda kullanılan veri ve yöntemler hakkında kısa bir değerlendirme yapılmıştır. Üçüncü bölümde ise Bağlar örneklemindeki suç korkusu değerlendirilmiştir.

\section{SOSYAL KONTROL PERSPEKTIFI}

Suç korkusunu ele alan toplumsal yaklaşımlar ikiye ayrılmaktadır. Her iki yaklaşım da suç korkusunu bir dizi farklı toplumsal faktörün değişmesinden veya bozulmasından kaynaklanan genel bir endişe durumunu yansıttığını (Covington ve Taylor, 1991) savunmaktadir. Ancak toplumsal sorun perspektifi veya sosyal problem yaklaşımı suç korkusunu makro düzeyde incelemekte ve onu toplumsal alg1 ekseninde açıklamaktadır (Sipahi, 2017). Toplumsal sorun perspektifi, daha çok bireylerde oluşan suç korkusunun toplum içerisindeki olayların yorumlanması veya aktarımıyla yakından ilişkidir. Özellikle medya suç korkusunda önemli bir etkiye sahipken, kişiler bu açıdan dolaylı olarak mağduriyetlik yaşamaktadırlar. Medya üzerinden aktarılan haberler kişilerin güvenlik konusundaki algılarını önemli bir şekilde biçimlendirmektedir (Gökulu, 2018). Medya üzerinde çıkan suç haberlerinde olayların izleyiciye görsel ve işitsel bir şekilde sunulması, bireylerin çevrelerinin güvensiz bir ortama dönüşebileceği algısını da bilinçaltlarına yerleştirerek mağdur olma riskini yaygınlaştırabilmektedir (Irmak ve Balkanlıoğlu, 2013).
Sosyal kontrol ya da toplumsal düzensizlik perspektifi ise suç korkusunu hem bölgesel ölçekte açıklamaya çalışmakta hem de fiziksel ve sosyal bozulmalara vurgu yapmaktadır (Sipahi, 2017). Farklı özellikteki mahalle türlerinin suça ve suçluluğa elverişli veya elverişsiz koşullar yaratma üzerindeki etkilerini ele almıştır. Özellikle bazı mahallelerdeki sosyal örgütsüzleşmelerin bireylerdeki ortak hedefleri gerçekleştirememesine ve kronik sorunları çözememesine neden olmaktadır. Yoksulluk, etnik heterojenlik ve zayıf sosyal ağlar vs. bir mahalle halkının toplumdaki davranışlarını kontrol etme kapasitesini azaltmakta, suç olasılığını artırmakta ve sosyal çözülmeye yol açmaktadır (Kubrin ve Weitzer, 2003). Özellikle gürültülü komşuluklar, duvar yazıları, sokak köşelerinde dolaşan gençler, sokaklardaki sarhoşlar, etrafa atılmış çöpler ve terk edilmiş evler sosyal ve fiziksel olarak bir düzensizliğin belirtileri olabilmektedir. Dolayısıyla bireyler yakın çevrelerini bir tehdit olarak algıladıklarında sembolik olarak bir suçla kuşatıldıklarını hissedebilir (Eve ve Eve, 1984) ve bu fiziksel ve sosyal çevrede oluşan bozulma orada yaşayan bireylerin bakış açılarını olumsuz yönde etkileyerek daha fazla korkuya sebebiyet vermektedir (Kubrin ve Weitzer, 2003). Elbette bu durum, söz konusu çevrede yaşamakta olan insanların güvenlik algılarını olumsuz yönde etkilerken, suç korkusunun da belirleyicisi olabilmektedir (Sipahi, 2017).

\section{VERİ VE YÖNTEM}

Suçu hem toplumsal hem de mekânsal açıdan incelemeyi amaçlayan coğrafya veya çevresel kriminoloji gibi disiplinler için, ilgili olgu üç farklı yersel yapıyla ilişkilendirilmektedir. İlki suçu çeken, ikincisi suçluyu üreten, sonuncusu ise negatif yerlerdir (Brantingham ve Brantingham, 1995). İlk iki kategori suç araştırmacıları için odaklanılması gereken bölgeleri işaret etmektedir. Böyle bir husus kısmen suç korkusu için de geçerlidir. Çünkü suç korkusu özellikle bazı kentsel mekânlara karşı güvensizlik hissini pekiştirdiği gibi sosyal tabakaların birbirlerine kuşkuyla baktığı birer yer halini alabilmektedir (Sipahi, 2016). Bu durum suçun en yoğun olduğu ve sıcak noktalar olarak adlandırılan alanlarda daha fazla göze çarpmaktadır (Block ve Block, 1995). İfade edilen yaklaşımla çalışmanın ilk veri kaynağını Isparta şehri suç sayıları oluşturmaktadır. Isparta İl Emniyet Müdürlüğü tarafından mahallelere göre düzenlenen söz konusu veri ile ş̧ehirsel alanda suçun yoğunlaştı̆̆ı sahalarkolaylıklayorumlanabilmektedir. Ancak suç sayısı suç korkusunu yorumlamak adına sadece bir başlangıç noktası oluşturmaktadır. Nitekim suç korkusu gerçekleşen bir suçtan daha çok suça maruz kalma ihtimaline karşı bir tepkiyi ifade etmektedir. Dolayısıyla korku hissini açıklamak için, ona neden olan mekânsal veya toplumsal özellikleri yansıtan verilere de ihtiyaç duyulmaktadır. 
$\mathrm{Bu}$ sebeple çalışmanın ikinci veri kaynağını mahallenin bir takım mekânsal özelliklerini yansıtan bilgiler oluşturmaktadır. Suç korkusunu her ne kadar doğrudan yansıtmasa da mekân ve toplum arasındaki diyalektik ilişki dikkate alındığında mahallenin özellikle morfolojik yapısındaki sorunlar korku hissinin oluşmasına, güçlenmesine ya da korkuya neden olabilecek suçların yaşanmasına ortam hazırlayabilmektedir. Bu kapsamda alan yazında sıkça vurgulanan sokak 1şıklandırmaları arazi çalışmaları ile tespit edilmiş ve Isparta Belediyesi'nden temin edilen yol verisi ile ilişkilendirilmiştir. Yine arazi çalışmaları ile mahalledeki binaların mesken dışı kullanımları da belirlenerek bulundukları parseller itibariyle görselleştirilmişsir. Ayrıca araştırmada sokaklar itibariyle rayiç değerlerin görselleştirmesine de yer verilmiş̧ir. Rayiç değerler mahalledeki arazinin değerinin yanı sıra bölgedeki ekonomik durum ve yaşam kalitesi hakkında da dolaylı bilgi vermektedir. Rayiçlerin sokaklar/caddeler itibariyle haritalandırılması ile çalışma alanının diğer mahallelere göre ve kendi içerisinde bölgesel manada karşılaştırılmasına gidilmiştir.

Araştırmada kullanılan üçüncü veri kaynağı suç korkusunu ve onun toplumsal yönünü belirlemeyi sağlayan görüşmeler oluşturmaktadır. Bu kapsamda her mahallenin kendine özgü bir yapısal özelliği olduğu düşünüldüğünde Bağlar (Isparta) Mahallesi'nin gerek fiziki gerekse de sosyal yapısı suç ve korku durumunu önemli derece etkileyebilmektedir. Suç korkusunu değerlendirirken, mahalleden ve suçla ilişkili kişilerden endişe veya suç korkusu duyan kadınların korku deneyimleri bu açıdan bir alan araştırmasıyla belirlenmek istenmiştir. Araştırma alanında görülen suç olayları veya medyada çıkan bazı haberler, mahallede suça bulaşmış bireylerin varlığı ve aynı zamanda bazı olaylara tanıklık bu anlamda Bağlar Mahallesi'nin tercih edilmesinde etkili olmuştur. Bu noktada kadınların karşılaştıkları sorunlar veya deneyimledikleri olaylar nitel araştırma desenlerinden durum çalışması seçilerek belirlenmeye çalışılmıştır. Özellikle tesadüfi örnekleme yöntemi ile mahallede yaşayan kadınlarla görüşmeler gerçekleştirilmiştir. Bryman (2007)'a göre, basit tesadüfi örneklem yöntemi iyi bir örneklem çerçevesi oluşturulduğunda ve coğrafi açıdan belirli bir bölgeye odaklanıldığı zaman kullanışlı olabileceğini belirtmektedir.

Diğer yandan nitel çalışmalar bireylerin yaşadığı suç korkularının çok yönlü ve dinamik olarak keşfedilmesini kolaylaştırmaktadır (Hollway ve Jefferson, 1997). Feminist araştırmalarda sosyal yaşam, günlük deneyimler ve ilişkilerin anlamını derinlemesine anlamak ve açıklamak amacıyla niteliksel yöntemlere başvurulmaktadır. Özellikle araştırmaya dâhil olanların kendilerini ifade edebileceği, duygularını ve düşüncelerini rahatlıkla paylaşabilecekleri görüşme teknikleri kullanılmaktadır ki, bu süreçte öznel deneyimler de önemli biryer tutmaktadır (Kümbetoğlu, 2008). Bu bakımdan çalışmada korkunun kadınların yaşam pratiklerini nasıl etkilediği ve günlük rutinlerinde ne gibi değişiklikler yaptığı mahallenin kendine has mekânsallığ 1 üzerinden değerlendirilmiştir. Nitekim kent mekânlarında yaşayanların mekânı algılayış ve kullanış şekilleri ve deneyimledikleri olaylar öncelikle araştırılması gereken bir husustur. Bu amaçla da çalışmada kişinin kendini güvende veya emniyette hissetmesi açısından çevrenin önemine vurgu yapan sosyal kontrol veya toplumsal düzensizlik perspektifinden yola çıkılmıştır.

Çalışmanın amacı ve kapsamı doğrultusunda ise katılımcılara;

- Bağlar Mahallesi'ni neden tercih ettikleri ve yaşadikları süre,

- Mahalle sakinlerini taniyıp tanımadiklarl,

- Bu mahalleden taşınmayı düşünüp düşünmedikleri,

- Mahalle hakkindaki genel düşünceleri,

- Bir suçtan kaynaklı mağduriyetlik yaşayıp yaşamadıkları,

- Onları en çok korkutan şeylerin neler olduğu,

- En çok korku hissettikleri zamanlarin ne olduğu,

- Bu mahallede kendilerini güvende hissedip hissetmedikleri,

- Kendilerini veya yakınların korumak için ne gibi önlemler geliştirdikleri

şeklinde belli başlı sorular yönetilmiştir.

Araştırmada, 12 kadın, 3 erkek olmak üzere toplam 15 kişi ile Nisan 2019 - Haziran 2019 tarihleri arasında görüşmeler yapılmışıır (Tablo 1). Çalışmaya erkek katılımcıların dâhil edilmesinin sebebi ise bazı gömülülükleri ortaya çıkarmak içindir. Özellikle mahallenin genel görünümü, mahallede yaşanan olaylar ve bunların mekânsal etkileri üzerinde değerlendirmelere sunacağ1 katkılar yüzündendir. Yapılan görüşmeler K1, K2,...

Tablo 1: Katılımcıların Genel Özellikleri. Table 1: General Features of the Participants.

\begin{tabular}{lccc}
\hline & Cinsiyet & Yaş & Meslek \\
\hline K1 & Kadın & 28 & Öğrenci \\
K2 & Kadın & 38 & Iş̧̧̧i \\
K3 & Kadın & 37 & Ev Hanımı \\
K4 & Kadın & 28 & Iş̧çi \\
K5 & Kadın & 32 & Memur \\
K6 & Kadın & 28 & Ev Hanımı \\
K7 & Kadın & 32 & Iş̧çi \\
K8 & Kadın & 45 & Ev Hanımı \\
K9 & Erkek & 38 & Isşsiz \\
K10 & Erkek & 40 & Muhtar \\
K11 & Kadın & 22 & Öğrenci \\
K12 & Kadın & 50 & Ev Hanımı \\
K13 & Kadın & 56 & Ev Hanımı \\
K14 & Kadın & 80 & Ev Hanımı \\
K15 & Erkek & 46 & Isşsiz \\
\hline
\end{tabular}


K15 şeklinde kodlanarak, toplanan veriler betimsel yolla analiz edilmiştir. Betimsel analiz Yıldırım ve Şimşek, 2013'e göre ilk başta bir çerçeve ya da sınır oluşturma, oluşturulan çerçeveye göre verilerin işlenmesi, daha sonra bulguların tanımlanması ve yorumlanması aşamalarına göre yapılmaktadır.

$\mathrm{Bu}$ doğrultuda "stnırlandırllan bedenler, kişisel güvenlik sorunsalı, yabancı uyruklu korkusu ve aile bireylerine karşı duyulan suç korkusu" başlıklarıyla görüşmeler gruplandırılmıştır. Nitekim şimdiye kadar kadınların yaşadığı suç korkularını inceleyen çalışmalarda genellikle nicel araştırma yöntemleri kullanılmıştır. Yöntem ve saha araştırmalarıyla kadınların korku deneyimlerini belirlemeye çalışan bu araştırma insan ve mekân bağlamında ele alınmış ve coğrafi bir bakış açısıyla incelenmiştir.

\section{BULGULAR}

\subsection{Mekânsal Öncüller/Sonuçlar}

Her ne kadar mahalle kavramının tanımlanması konusunda bir genel kabul olmasa da (Lee, 1968; Gaster, 2001) kelime çoğunlukla fiziki ve toplumsal bir bütünlüğe işaret etmektedir. Birçok açıdan sınırları belirli bir fiziki oluşum (çoğunlukla belirli yollarla çevrelenmiş bütünlük arz eden bölge) veya toplumsal anlamda bir kominite fikrini yansitmaktadır. $\mathrm{Bu}$ özellikleri nedeniyle de kent araştırmaları için bir mikro ölçek veya bir araştırma ünitesi niteliği taşımaktadır. Eğer idareciler tarafindan statüsü söz konusu özelliklere (toplumsal ve fiziksel) göre belirlenmiş ise her bir mahalle kent içerisindeki farklılıkları veya benzerlikleri analiz etmek için başat birimler haline gelmektedir. Böyle bir yaklaşım da kentin gelişimi ve mevcut dokusu hakkında özgün sonuçlar üretmeye yardımcı olmaktadır.

Bu kapsamda Bağlar Mahallesi hem çevresindeki benzer ünitelere göre hem de Isparta şehrinin genel görünümü bakımından kendine özgü niteliklere sahiptir. Mahallenin eski sakinleri mahallenin kırsaldan göç edenlerin düzensiz bir şekilde yerleşmesi ile gelişimin başladığını vurgulamaktadırlar. Mahalledeki parsellerin ve yolların oluşturduğu sorunlu morfolojik yapı da bunun bir göstergesidir. Özellikle yolların belirli bir yöndeki uzunluğunun az olması ve yolların darlığı kadınların belirli bir saatten sonra yürürken korku hissine kapılmalarına neden olmaktadır. Kimilerinin de vurguladığı gibi korku düzeyi savunmasız kişilerin çevresinde ne olduğu hakkında kesin bir kanıya varamadığında yükselmektedir (Brantingham ve Brantingham, 1995). Bağlar Mahallesi’nde yol ağının oluşturduğu düzensiz yapı, yolların hemen bitişiğinde (birçok durumda kaldırım dahi yok) konumlanan binalarla birleşince birçok yerde 100 metre ötesi için bir kestirimde bulunulamayan labirente dönüşmektedir. $\mathrm{Bu}$ husus suç korkusunun sadece 1şıklandırılmayan sokaklarda değil aynı zamanda düzensiz ve belirli bir görüş açısının ötesinde uzunluğa sahip olmayan yollar için de geçerli olduğunu vurgulamaktadır. Nitekim Bağlar'da birkaç sokak haricinde tüm yol ağı 1şıklandırılmasına karşın, kişiler için yolda az ileride kiminle karşılaşacakları fikri tamamen belirsizdir (Şekil 1). Belirli

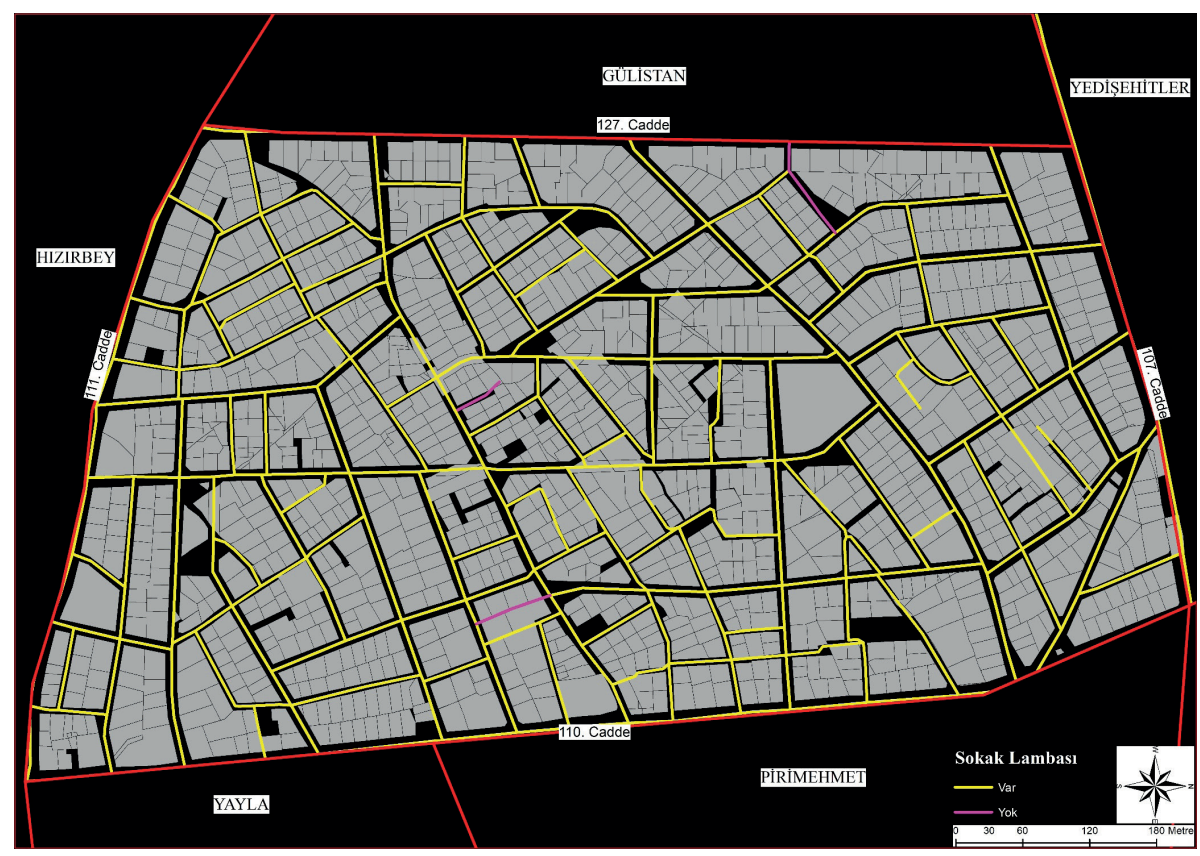

Şekil 1: Bağlar Mahallesi'nde Sokak Ağının Oluşturduğu Düzensiz Yapı ve Sokakların Işıklandırma Durumu. Figure 1: Irregular Structure Created by Street Network in Bağlar Neighborhood and Lighting Status of Streets. 
saatlerden sonra mahalledeki tenhalık endişe düzeyinin daha da artmasina sebebiyet vermektedir.

Mahallenin fiziki yapısına yansıyan bir diğer husus ise hem ilk yerleşen hem de sonradan gelen hanelerin gelir düzeyinin oldukça düşük olmasıdır. Mahalle sakinlerine göre mahalleye ilk yerleşenlerin önemli bir bölümü kırsal kökenli olan hanelerden oluşmaktaydı. Zamanla ekonomik gücü iyi olan bazı aileler buradan taşınarak farklı mahallelere geçmeye başlamış ve mevcut binaların boş kalmaması için gelir seviyesi daha düşük bireylere kiraya verildiği ifade edilmiştir. Bunun dışında bazı binaların eskimesi ve mevcut ev sahiplerinin evlerini tadilattan geçirmemeleri ve yenilememeleri, evlerin başıboş ve terkedilmiş halde kalmasına (Fotoğraf 1) yol açtığı da vurgulanmıştır. Mahalledeki bazı konutların bu şekilde harabeleşmeye ve metruklaşmaya başlaması belli başlı olumsuzluklara da sebep olmuştur. Bu şekilde mahalle fiziki yapı itibariyle suç olaylarının yaşanmasına neden olan veya suça ortam hazırlayan bir takım özellikleri bünyesinde barındıran bir mekâna dönüşmüştür. Nitekim bazı konutlardaki duvar yazıları, kamu mallarına verilen zarar veya vandallık gibi çeşitli olumsuzluklar suçun mekân üzerine yansıyan izdüşümlerindendir (Fotoğraf 2).
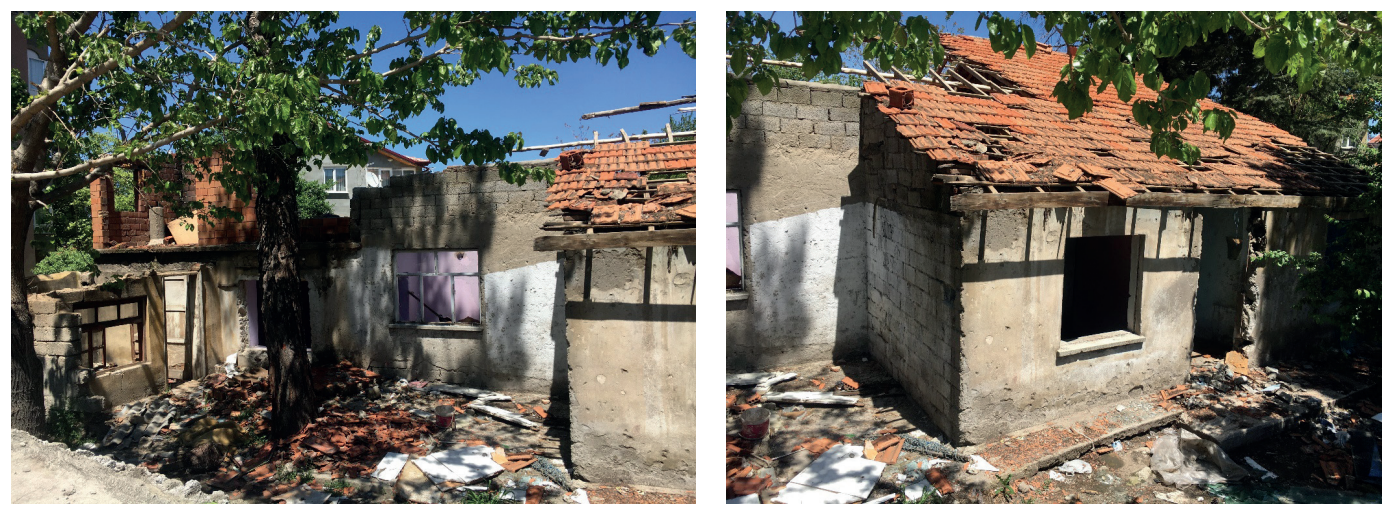

Fotoğraf 1: Mahalledeki Terkedilmiş ve Harabe Binalar.

Photo 1: Abandoned and Ruined Buildings in the Neighborhood.
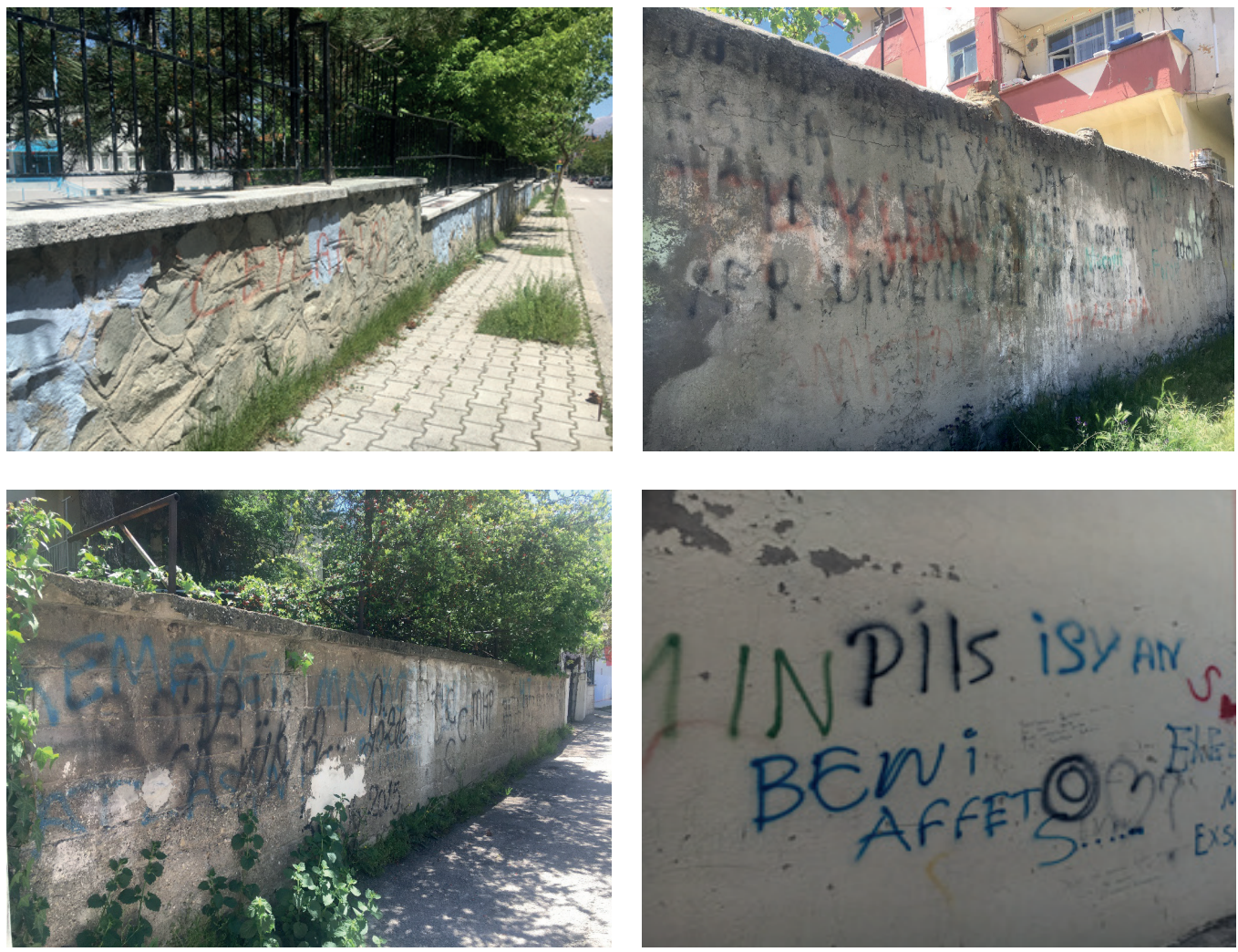

Fotoğraf 2: Mahallede Bazı Bina ve Duvarlarda Görülen Yazılar. Photo 2: Writings on Buildings and Walls in the Neighborhood. 
Bu kapsamda gelir düzeyindeki düşüklük ve fiziki yapısındaki düzensizlikler Bağlar Mahallesi'ni çevresinden ve Isparta şehrindeki diğer mahallelerden ayırmaktadır. Arsa rayiçlerindeki zıtlık söz konusu kanıyı desteklemektedir. Hem mahalle içerisinde hem de çevre mahallelere göre Bağlar bir çöküntüleşme eğilimini yansıtmaktadır (Şekil 2). Mahalledeki parsellerin küçüklüğü, mülkiyetin parçalı olması ve yerel halk da mahallenin olumsuz imgesi bir yeniden yapılanmayı veya yaşayan kişilerin kenti kendi isteklerine göre şekillendirmesini engellemektedir. Ífade edilen sorun kent araştırmalarında sıkça vurgulanan insan mekân diyalektiğinde (Soja, 1980; Harvey, 2009; Harvey, 2016) bir uyumsuzluğa neden olmaktadır. Böyle bir kalıpta mahalle sakinleri mekânı istedikleri gibi şekillendiremezken fiziki yapı kişilerin hayat standartlarına uymamakta ve yaşam düzeylerinde bir gerilemeye neden olmaktadır. Özellikle mahalleye yeni taşınanlar veya mahallenin genç sakinleri için söz konusu husus daha da belirginleşmektedir. Sıralanan düzensizlikler ve karmaşa mahallede yaşayanların sürekli değişmesine de neden olmaktadır. $\mathrm{Bu}$ süreçte geliri yükselip başka mahallelere göç eden olduğu gibi düşükgelirlihanelerin veözellikle apartların yaygınlaşmasıyla öğrenci ve yalnız yaşayanların bir karşı göçü bulunmaktadır. Bu akış nispeten şiddetli sayılabilecek bir düzeyde gerçekleşmektedir. Nitekim binaların mesken dışı kullanımı incelendiğinde, özellikle apartlar ve mahalledeki geçiciliği yansıtan spotçuların yoğunluğu hemen göze çarpmaktadır (Şekil 3). Söz konusu durum mahallede bir kominite oluşumunu engellemekte hatta bir çatışmaya yol açmaktadır. Yeni gelenler eskileri, eskiler ise yenileri kabullenmekte sorun yaşamaktadır. Korku ise hem iki grup arasında hem de yeni gelenlerin kendi içerisinde gerçekleşmektedir.

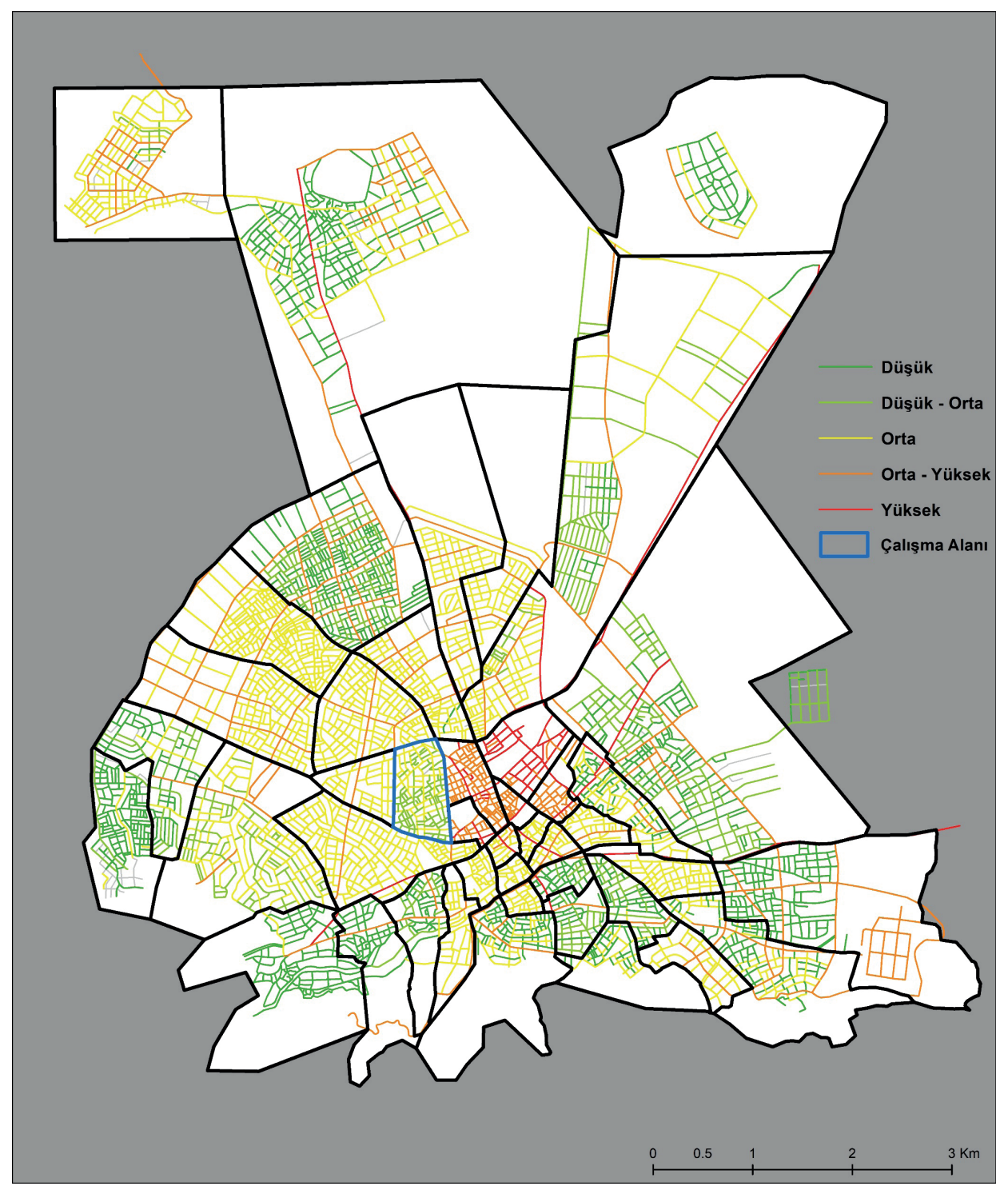

Şekil 2: Rayiç Değerlerinin Isparta Şehrinde Kademelenmesi.

Figure 2: Staging of Fair Values in Isparta City. 


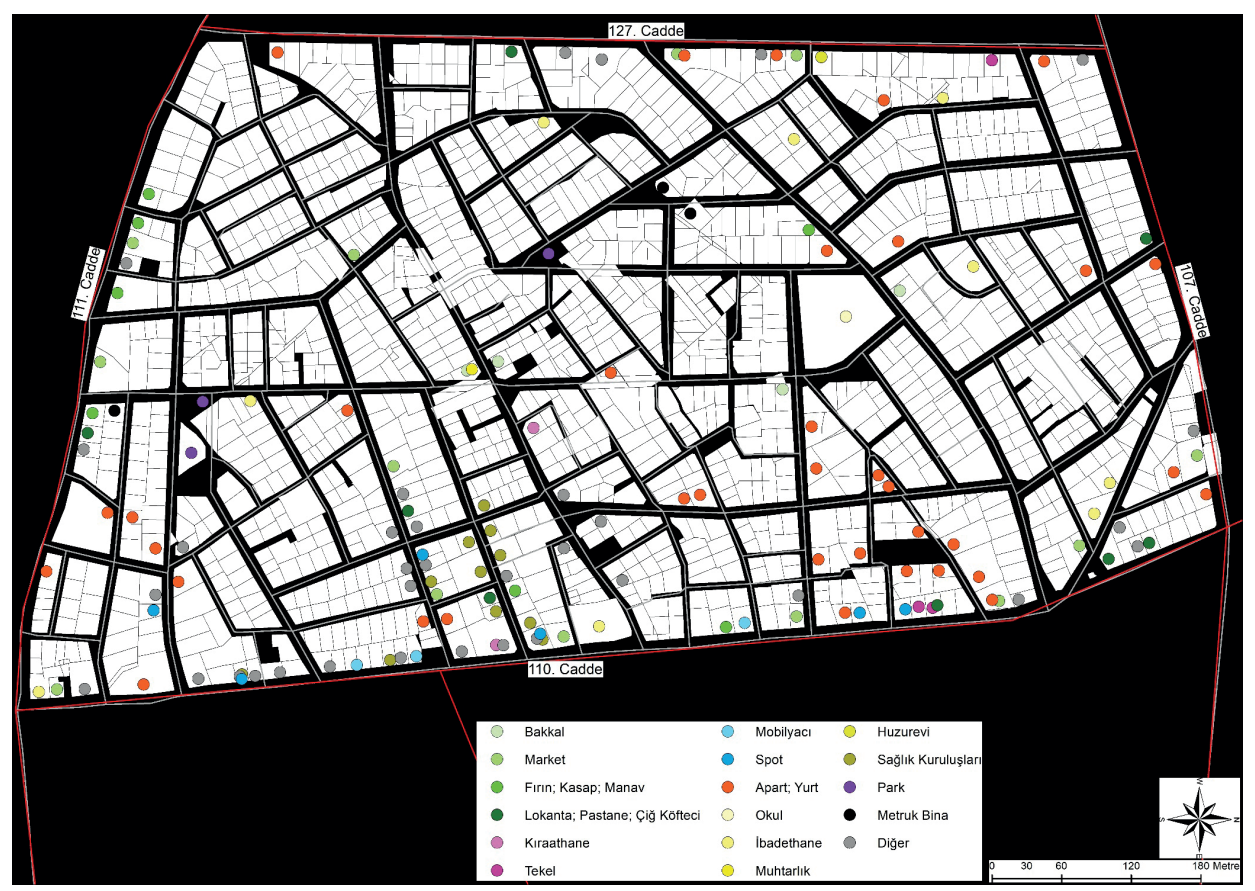

Şekil 3: Bağlar Mahallesi'nde Mesken Dışı Arazi Kullanımları.

Figure 3: Non-Residential Land Uses in Bağlar Neighborhood.

Bağlar Mahallesi'nde mekânsal dokudaki karmaşayı yansıtan bu örnekler aynı zamanda mahallenin suç istatistiklerinde de kendini hissettirmektedir. Isparta şehrinde suç oranının (10.000 kişiye düşen suç) oluşturduğu mekânsal düzen incelendiğinde bazı mahallelerin suç oranları açısından sıcak noktaları meydana getirdiği gözlemlenmektedir (Şekil 4). Bu mahallelerden Sanayi Mahallesi'nde iş yerine yönelik suçlar öne çıkarken, Bahçelievler Mahallesi'nde otogarın varlığı suç sayılarının artmasında etkili olmuştur. Merkeze yakın mahalleler arasında Pirimehmet Mahallesi’nin güneyi, Kutlubey, Çelebi, İskender ve Kurtuluş mahalleleri merkezi iş alanlarına yakın olmaları nedeniyle suç varlığı konusunda önemli mahalleleri oluşturmaktadır. Yayla ve Bağlar Mahallesi gibi konut alanları ile merkezi iş alanlarının bir arada bulunduğu mahallelerde ise suçun ve suçluluğun oluşmasına zemin hazırlayan faktörler çeşitlilik göstermektedir. Bağlar Mahallesi'nde daha çok hırsızlık, tehdit, aile içi şiddet, yaralama ve intihara teşebbüs gibi mala ve şahsa yönelik işlenen suçlar sıkça görülen suç türlerini oluşturmaktadır (Isparta İl Emniyet Müdürlüğü, 2018). Ancak bu duruma bağl1 olarak gelişen ve insanlar üzerinde oluşan endişe veya suç korkusunu yalnızca suç olaylarının varlı̆̆ıyla yorumlamak yeterli bir açıklama olmayacaktır. Çünkü suç korkusu yalnızca suça zemin hazırlayan yerlerdedeğil,suçluyuüretenmekânlardadagerçekleşebilmektedir. Yani suçlu (potansiyel suçlu) ile mağdur aynı mekânı paylaşmakta ve bundan dolayı da korku duyabilmektedir. Nitekim insanlar Isparta şehrinde suç oranının en yüksek olduğu merkezi iş alanlarında kendilerini güvende hissedebilirken, suçluyu üreten mekânlarda tedirginlik yaşayabilmektedir.

\subsection{Toplumsal Yorumlar}

\subsubsection{Sintrlandirtlan Bedenler}

Evin özel alanı içerisinde kadına yönelik saldırıların yanı sıra kadınların evin dışına çıkma korkusu da yaşamları için büyük bir sınırlama getirmektedir. Kadınlar, özellikle geceleri erkek egemen alanlarda yalnız kalmanın uygunsuz ve potansiyel olarak güvensiz olduğunu tecrübe ederek öğrenir. Kadınlar tarafından benimsenen baskın strateji ise, "tehlikeli zamanlarda, tehlikeli yerlerden" kaçınılmasıdır. Bu tür savunma taktiklerini benimsemekle kadınlar, sınırlı kamusal alan kullanımı ve işgaliyle aslında baskı altındadırlar (Valentine, 1989). Bu kısıtlı davranışlar, bireylerin kendilerini potansiyel mağduriyetten korumak için yaptıkları eylemlerdir (Ferraro, 1995). Stanko'nun da (1990) belirttiği gibi, kamu alanlarına kadınların erişimi, kadınsı yaralanabilirlik beyanlarının dolaşımıyla kısıtlanır. Kadınların evlerinin dışında bulundukları her an tetikte olmak zorunda olduklarını ima ederler (Ahmed, 2017). Çünkü bir kadının sıra dışı saatlerde tek başına sokakta olması bazen bir tehdit kaynağına dönüşebilmektedir. Bağlar Mahallesi'nde de farklı zaman ve mekânlarda kadınlar rahatsız edici davranışlarla karşılaştıklarını belirtmişlerdir: 


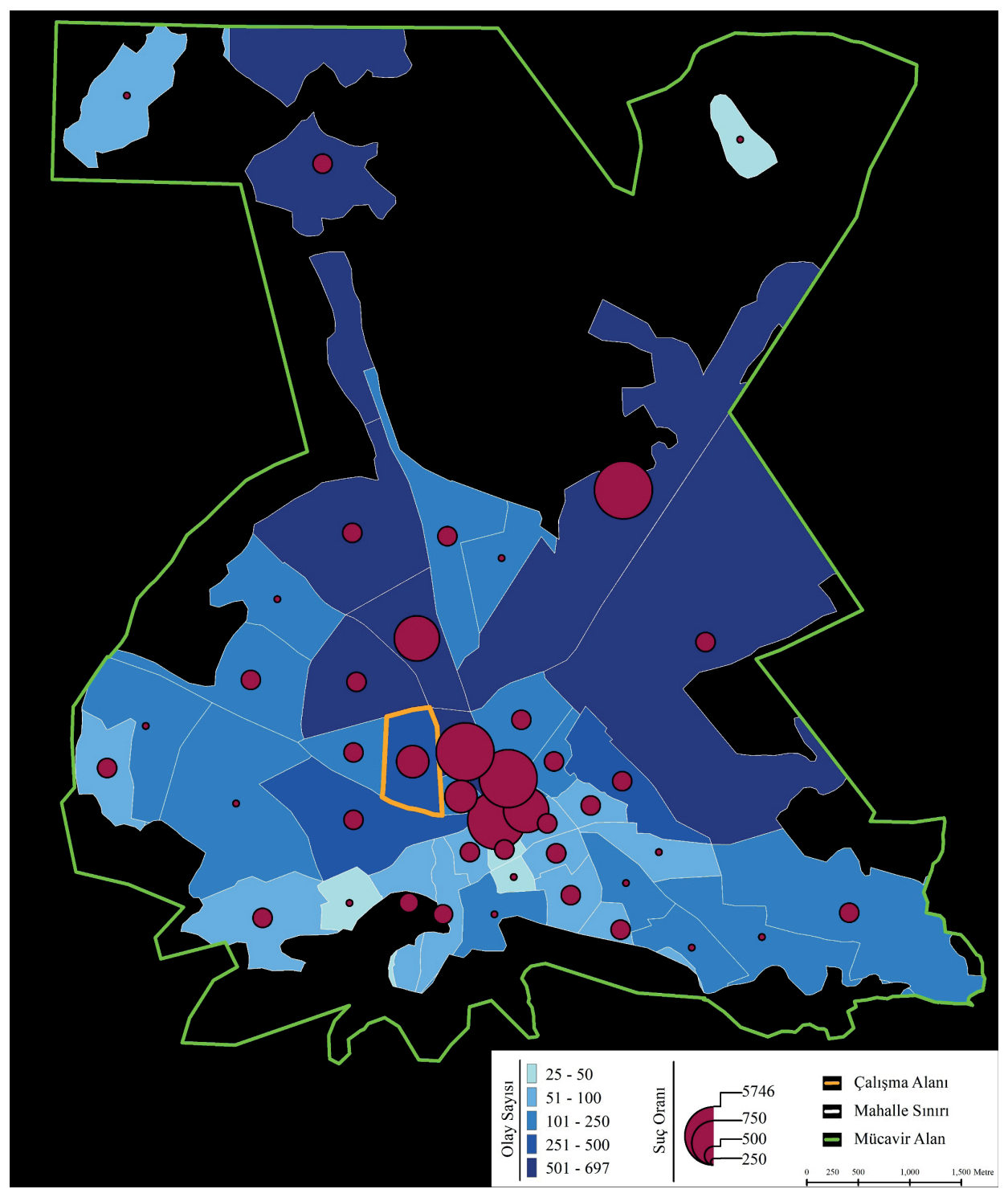

Şekil 4: Isparta Merkez Mahallelerinin Her 10.000 Kişiye Düşen Suç Oranı ve Suç Sayısı (2018). Figure 4: Crime Rate and Number of Crimes Per 10.000 People in Isparta Merkez Neighborhoods (2018). Kaynak: Isparta Belediyesi ve Isparta II Emniyet Müdürlüğü verilerinden yararlanılarak yazarlar tarafından çizilmiştir. Source: Drawn by the authors using data from the Isparta Municipality and Isparta Provincial Police Department.

“Gece markete çıkamiyorsun çünkü uyuşturucu kullanan insanlarla karşılaşabiliyorsunuz. Bakkala giderken bile ailenden biriyle gitmen gerekiyor. Burası tehlikeli bir mahalle, hirsızlıklar oluyor. 22 ylldir bu mahalledeyiz, kirada oturuyoruz. Konum olarak her yere yakın olduğu için burdayız. Konum olarak güzel bir mahalle ama insan olarak değil. Yabancı uyruklularla, Türk çocuklar sürekli bir atışma peşindeler.” (K11)

Bağlar Mahallesi fizikiyapısıitibariyle suçun gerçekleşmesine elverişli bir ortam sağlamasının yanı sıra suça bulaşmış veya suça meyilli bireylerin de bir arada bulunduğu bir mahalleye bürünmüştür. Sonradan yerleşenler dışında düzenli bir işi olmayan veya eğitim seviyesi düşük bireyler de bu mahallede bulunmaktadır. Bu konuda özellikle erkekler tarafından sözlï veya görsel taciz yaşayan kadınlar duygularını şu şekilde belirtmiştir:

"Geç saatlerde dışarı çıksak da aklımıza kötü şeyler geliyor. Bir gün eve dönerken bir araç durdu yanımda, isterseniz sizi evinize birakabilirim dedi. Kızdım ve gitti, çok korktum. Bu mahalle hiç iyi bir mahalle değil.." (K1). Benzer şekilde rutin olarak yapılan işe gidip gelme, güvenlik endişesi yaratabilir ve kadın bazı durumlarda risk altında kalabilir (Furedi, 2017):

"1 sene oldu ben buraya geleli. 1 senedir alı̧̧amadım. Maddi sıkıntılarım olmaya başladı, başka bir mahallede oturuyordum. 
Ucuz ve hesapl geldi bura, orda ev fiyatı yüksekti o yüzden buraya gelmek zorunda kaldım ama bu konuda hiç memnun değilim. Sabah işe erken gittiğim için ben gidene kadar takip etti birisi, kalp krizi geçirecektim. Hanımefendi bu saatlerde yalnız yürünür mü? Bu saatte nereye gidiyorsunuz diye laf attı. Insanın özgürlüğü yok. İşin gereği mecbursun gitmeye, çalışmak zorundasın. Şimdi giderken telefonla konuşuyormuşum gibi yapıyorum, başka çarem kalmadı çünkü. İnsan korkuyor kadınsın sonuçta, her an her şey olacakmış gibi düşünüyorsun.” (K2).

Erkekler daha güçlü olarak algılandığından, kadınlar kendi alanlarını fiziksel olarak istila eden erkekleri kontrol edemediklerini düşünürler. $\mathrm{Bu}$ şekilde, erkeklerin fiziksel görünüşlerini, kadınlar çoğunlukla bir tehdit unsuru gibi düşünür ve görünüşleri ile erkekler kamusal alana hâkim olabilirler. Çünkü kadınlar tarafından sınırlı bir şekilde kullanılan kamusal alanlar aslında ataerkilliğin mekânsal bir tezahürüdür (Valentine, 1990). Bu aynı zamanda bir kadının cinsiyetçi, ataerkil bir toplumda mağdur rolünün kendini savunamayacağını iddia eden feminist suç korkusu açıklamalarına da uymaktadır (Hilinski, vd., 2011). Bağlar Mahallesi'nde kadınların hissettikleri bu korku deneyimi aslında onları sınırlandırabildiği gibi günlük aktivitelerini de büyük ölçüde etkileyebilmektedir. Son zamanlarda mahalle güvenliğine yönelik sokaklarda bekçilerin dolaşıyor olması kadınları bir noktada rahatlatabilmiştir. Ancak herhangi bir olayın yaşanması ihtimalinde kadınlar tek başına kalabilmektedir. Bir erkek kadar kadının kendini savunacak bir güce sahip olmaması aslında onların her zaman tehlikeyle karşılaşma ihtimalini güçlendirmektedir.

\subsubsection{Kișisel Güvenlik Sorunsalı}

Bireylerin her şeyi güvenlik açısından düşünmesi günümüz toplumunun belirleyici niteliklerindendir. Güvenlikle ilişkili tehlike ve endişelerin varlığ 1 ise bir risk toplumunu işaret etmektedir (Furedi, 2017). Mahallede önemli bir güvenlik sorunsalının olduğunu belirten kadınlar kamusal alan dışında kendilerini güvende hissetmedikleri mekânlardan birisinin de evlerinde karşılaşabilecekleri riskler olduğunu vurgulamışlardır:

"Bundan birkaç yll önce bir oğlan çocuğu bizim çatının oraya çıkmış, elinde eldiven, sakall bir şey. Sen kimsin dedim, Mahmut adında biri oturuyormuş ona bakiyorum dedi. Telefonumun şarjı yoktu, aşağı iner inmez senin fotoğrafinı çektim dedim, hiçbir şey demedi kaçtı gitti." (K3). "Annemin evi de Bağlar Mahallesi'nde, onun evine de girmişti hırsız ama bir şey almadan çıkmış." (K4). "Apartta oturuyorum ben, yaklaşık 10 gündür evde yoktum. Işılkların yanmadığını görmü̈ş olmalılar ki gelmişler kapıyı zorlamışlar ama açamamışlar. Bende o an ki korkuyla polisi çağırdım." (K5).

Aslında buradaki korkunun temeli evden bir eşyanın çalınması değil, kadınların kendi güvenliklerini tehdit edecek bir olayın yaşanabilme ihtimalidir: "Doğduğumdan beri buradayım, yerlisiyim. Kendime ait küçük bir evim var. Çatıdan her şeyimi toplayıp çaldılar, polisi aradım, bir şey çıkmadı. Satıyorlarmış orda burda, arkasına kim düşecek, hırsız bu kim çaldı ne bilelim, aramaya mi gidelim? Hadi o çaliyorken varsam üstüne, benim kafama bir şey vursa öldürse beni, her şey olur." (K14). Gilchrist, vd., (1998)'nin bahsettiği gibi, kadınlar, hırsızlık sırasında saldırı gibi daha ciddi bir suçun olabileceğini düşündükleri için korku hissetmeleri bu nedenle doğaldır.

Özellikle mahallede yaşanan bazı hırsızlık olayları kadınların korkularını tetikleyebilmektedir. Buna yönelik kadınların büyük bir çoğunluğu evde yalnızken ya da evden ayrılırken çeşitli önlemler aldıklarını belirtmişlerdir. Işı̆̆ı açık bırakmak, kapının kilidini sürekli kontrol etmek veya evde yalnızken zil çaldığında kapıyı açmamak alınan tedbirlerden birkaçıdır. Bazı konutlarda, özellikle apartlarda ve iş yerlerinde olası durumlara karşı güvenlik kameraları mevcutken, bazı konutların pencerelerinde güvenlik amaçlı korkuluklar da bulunmaktadır. Ancak apartlarda insanların büyük bir çoğunluğu birbirini dahi tanımamaktadır ve dolayısıyla aparta giren birinin hırsız olup olmadığı da belli değildir. Bu konuya yönelik bir katılımcının apartlar hakkındaki düşünceleri şu şekildedir:

"İnsanların bir kısmı mevcut eski binalarını, boş arsalarını aparta çevirdiler, geliri iyi olduğu için. Apartlarda ilk etapta ögrenciler kalıyordu, arkasindan farklı mesleklerden insanlar da kalmaya başladı. Aparta giren çıkan belli değil, denetim yok, insanlar suça karışabiliyor.” (K10).

\subsubsection{Yabancı Uyruklu Korkusu}

Bağlar Mahallesi'nde bazı konutlardaki kira fiyatlarının ucuzluğu yabancı uyruklu bireylerin bu mahalleye yoğun olarak yerleşmesine neden olmuştur. Sadece bu mahallede olmamak kaydıyla Türkiye'nin birçok bölgesine dağılan yabancı uyruklu bireylerle bir arada bulunmak zaman içerisinde problemlere de sebep olmuştur. Konunun sosyo-ekonomik, politik ve psikolojik boyutunun yanı sıra göçmenlere yönelik davranış kalıpları da değişiklik göstermektedir. Özellikle yaşadıkları yerleri göçmenlerle paylaşmak istemeyen pek çok söylem bulunmaktadır: "Yabancıların bir zararı yok günahın almayalım, olmasa daha iyi olur tabi. Herkes memleketine gitse 
iyi olur ama yapacak bir şey yok, herkes olduğu gibi yaşasın memleketinde." (K13). Tabi kadınların göçmenlere yönelik algıları ve bakış açıları farklı olup, yabancı olarak nitelendirdikleri insanlardan zarar görebilecekleri duygusu da yerleşmiştir. Bu durum güvenlik endişesiyle de ilişkili olarak toplum açısından giderek artan bir tedirginliğe yol açmıştır: "Yabancı uyruklu insanlar çok fazla, bakışları, konuşmalarl, hareketleri çok rahatsı edici. Özellikle çalıştığım markete çok geliyorlar ve sürekli bir sorun çıkarma peşindeler.” (K4). "Bu mahallede oturmak istemiyorum, çevre hoş değil hep mülteci dolu o yüzden sevmiyorum bu mahalleyi" (K2). "Yabancllar bizden daha rahat. Onların gelmesiyle olaylar daha da çoğaldı." (K6).

Zenofobi yani yabancı korkusunun kaynağı insanların onlar hakkındaki bilgi yetersizliğinin yanı sıra bu tür insanlarla nasıl başa çıkacaklarını bilmemeleri de onları tehdit olarak görmelerine neden olmaktadır (Mogekwu, 2005). Başka bir ifadeyle Rathzel (2002), korkunun temelde yabancılardan değil de, insanların onları tehlike yaratabileceklerini düşünmelerinden kaynaklandığını belirtmektedir. Özellikle, yabancıların suçlu, katil veya uyuşturucu satıcısı gibi kavramlarla bir arada anılması bu korkuyu artırmaktadır (Demirel, 2017). Örneğin bu korkunun oluşmasında bir kısım yabancının karanlık işlerle uğraşıyor olması onlara karşı önyargıyı ve tepkiyi güçlendirmektedir: "Bizim apartta geçen senelerde iki kişiyi uyuşturucudan tutuklayıp götürdüler, yabancl uyruklulardı. O günden sonra aparta girerken hep korkuyorum." (K5). "Geçenlerde kadinin birisi için aşırı dozdan uyuşturucudan öldü, evinde ölü bulundu dediler." (K2). "Mecbur olmadan dışarı çıkmak istemiyorum. İşe gitmek dışında tek başıma dışarı çıkmak beni korkutuyor, özellikle geceleri.. (K4). Yaşanan bu durumlar ister istemez insanlar üzerindeki tedirginliği artırmakla kalmayıp bir genellemeye de itmektedir. Ancak bir kısım yabancının uyuşturucuyla uğraşıyor olması bütün yabancı uyrukluları potansiyel olarak suçlu göstermez, nitekim böyle bir değerlendirme doğru da olmaz. Buna yönelik diğer mahalle sakinleri şunları belirtmiştir:

"Doğma büyüme bu mahalledeyim, kendimi güvende hissediyorum. Herhangi bir olay yaşamadım ama etrafta duyduklarım oldu. Çok iyi komşuluklarım var, yabancı uyrukluların bir zararl yok, kimsenin hakkina girmek istemem. Ama istemeyen ve zarar verenler var, bizim ne olacağımızı kim bilir?" (K12). "Komşularla aram iyi, ben daha kimseyle dövüş kavga etmedim yaşım 80. Yabancı komşularımızı da seviyoruz, baktık, yardım ettik iyi kötü. Biz komşular hepimiz bakarız bunlara. Sevdik garip ordan gelmişler, buraya geldiklerinde aç mısınız? Susuz musunuz sorduk biz de kötülük yok, başka kötülük edenler varsa vardır, 5 parmak düzgün olur mu?" (K14). Elbette herkesin yabancı uyrukluklara karşı davranışları aynı değildir. Hatta mahallede yaşayan yabancı uyruklu bireyler, komşularının yaklaşımlarından memnun olduklarını da belirtmişlerdir. Bir tercüman aracılığıyla görüşme yapılan Afganistanlı bir göçmen "Akrabalarımızın büyük bir çoğunluğu bu mahallede. Komşular da yardım ediyor bize." (K15) şeklindeki ifadeleriyle aslında komşuluk ilişkilerinin de iyi olduğunu vurgulamıştır.

\subsubsection{Aile Bireylerine Karşı Duyulan Suç Korkusu}

Bağlar Mahallesi'nde kadınlar kendi yaşadıkları ve deneyimledikleri bireysel korku dışında çocukları için daha fazla korku duyabilmekte ve endişe yaşayabilmektedir. Bu durumun yaşanmasında bazı ailelerin gençlerinde uyuşturucu ve yasaklı madde kullanıcılarının olduğu belirtilmiştir. Özellikle gece geç saatlerde okul bahçesinde veya parklarda kendi aralarında veya sokaktan geçenlerle kavga ettikleri bile görülmüştür. Mahalleli tarafindan bu tarz grupların birer suç makinasına dönüştüğü ve potansiyel olarak suç işleyebilecek birer birey olduğu ifade edilmiştir. Özellikle aileler çocukları açısından daha fazla kuşkulanmakta ve her koşulda çocuklarına insan ilişkilerinde adeta bir set çekmektedirler. Bu şekilde koruyucu pek çok davranış özellikle kadınlar tarafından daha belirgin bir hal almıştır. Çocuklara yönelik medyaya yansıyan haberler de mahalledeki kadınları bu konuda daha tedbirli olmaya itmiştir. Günümüzde çocuklara yönelik işlenen suçlar artık her kesimi tesiri altına almış ve insanları hiç kimseye güvenemeyecek bir duruma getirmiştir. Yapılan görüşmelerde de bu durum açıkça ifade edilmiştir:

"Küçük çocuğum var onu bile dişarlya oynamak için çıkaramıyorum. Parka giderken yanında da olsam korkuyorum bir şey olacak diye." (K7). "Yalnız çıkmıyoruz sokağa, çocukları da yalnız bırakmiyoruz." (K6). "Çocukları zor gönderiyorum sokağa, her türlü insan var.” (K8).

Özgeci korku ya da diğerleri için duyulan korku olarak ifade edilen bu durum, aile fertlerine (çocuk, akraba, eş vs.) veya etrafında değer verdikleri ve önemsedikleri kişilere karşı hissettikleri korkuların kişisel korkulardan daha yaygın ve çoğunlukla daha yoğun olduğu vurgulanmaktadır (Warr ve Ellison, 2000). Çünkü çocukların herhangi bir olaya maruz kalma düşüncesi bile ebeveynler açısından ürkütücü olabilmektedir. Elbette bu düşünce içinde yaşadığımız toplumun giderek güvensizlik temelli inşasıyla ilişkilidir.

Amerikalı bir sosyal bilimci, komşusuz mahalleler kavramını üretirken, bir arada bulunan ve birbirinin yakınında olan 
bireylerin aslında birbirinden oldukça izole şekilde yaşayan kişiler olduğunu vurgulamıştır. Bir korku kültürüyle donatılmış insanlar birbirlerinden uzaklaşarak bir açıdan da birbirlerine yabancılaşmıştır (Furedi, 2017). Korkunun dişavurumuyla ifade edilen bu semptomlar mahalledeki kadınlar tarafindan "Herkesten her şey beklenir." düşüncesini daha da pekiştirmektedir. Dolayısıyla topluma yansıyan bu güvensizlik inşası, insan ilişkilerini de bir noktada köreltmektedir.

\section{SONUC}

Kentin önemli bir parçası olarak nitelendirilen mahalleler küçük birimler olmalarının yanı sıra kendi içerisinde bir takım güvenlik meselelerini de barındırmaktadır. Bağlar Mahallesi de kendine özgü güvenlik sorunlarıla zaman zaman öne çıkabilmektedir. Özellikle birçok kişinin hafizasında çok da tekin olmayan, güvensiz bir yer olarak tanımlanmaktadır. Gerek toplumsal gerekse de fiziki görünümler bu anlamın güçlenmesinde önemli bir etkiye sahiptir. Mahallenin genel karakteristiği ve burada yaşayan kişi tipolojileri konu açısından önemli ipuçları sunmaktadır. Eski, bakımsız ve görünüş itibariyle metruklaşmaya yüz tutmuş bir takım binalar mahallenin genel profilini açıklama konusunda önemli bir rol oynamaktadır. $\mathrm{Bu}$ konuda mahalle muhtarının açıklamaları oldukça önemlidir:

"Binaların, evlerin metruklaşmaya başlaması binaların eskimesi ve mevcut ev sahiplerinin masraf etmeyerek evleri başıboş bırakmalarl, evleri yenilememeleri, evleri tadilattan geçirmemelerinden dolayı kiraları biraz daha düşük ve bu ucuz kiralar yüzünden günübirlik insanların yaşadlğı bir mahalleye dönüşmüş̧ür.” (K10). Böylelikle zaman zaman farklı olayların vuku bulduğu ve farklı kişilerin birlikte yaşadığı mahalle, kendine has yapısıyla suç ve suçluya zemin hazırlayan bir ortam yaratmıştır. Özellikle mahallede bulunan bazı konutlar çeşitli türde suça karışmış bireylerin yaşadığı bir mekân olmuştur. Bu durumun yaşanmasında ise mahalleye kentsel dönüşüm faaliyetlerinin girmemesinin de bir etkisi olduğu ifade edilmektedir:

"Mahallenin en büyük sikıntılardan bir tanesi de kentsel dönüşümün gelmemesidir. Bunun sebebi de eski mahalle olduğu için mevcut evlerin metrekaresinin düşük olmast, iki katll veya üç katlı evlerin olmasından dolayı gerek mirasçı sayısının çok olması gerekse de ev/mülk sahipleri (müteahhitler veya inşaat firmaları işin ticari boyutunu düşündüğ̈̈ için) sıcak bakmamaktadır." (K10). Bu bakımdan görünüş itibariyle mahalle kentsel dönüşüme ihtiyacı olan bir mahalledir. Ancak dönüşüm faaliyetleri henüz gerçekleştirilememiştir. Bunun yerine bazı ev sahipleri eski binalarını veya boş arsalarını aparta dönüştürerek (Fotoğraf3) ticari açıdan önemli kâr sağlamalarının yanı sıra mahalleye farklı türde insanların yerleşmesinin de önünü açmıştır. Ayrıca bazı eski konutlardaki kiraların düşük olması da, dar gelirli ailelerin yerleşmesine neden olmuştur. $\mathrm{Bu}$ açıdan farklı kimliklerin bu mahalleye yerleşmesiyle çeşitlilik daha da artmış ve heterojen bir yapı oluşmuştur.

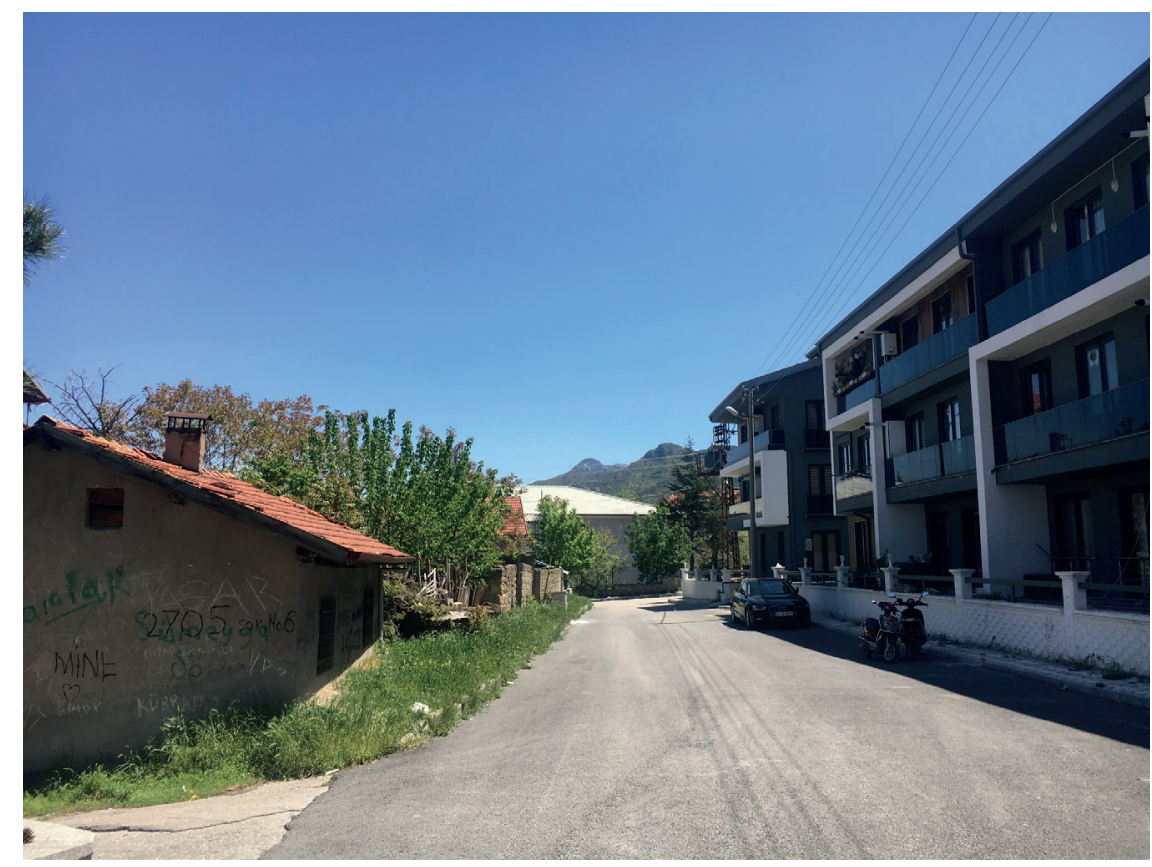

Fotoğraf 3: Mahallede Bulunan Apartlar.

Photo 3: Apartments in the Neighborhood. 
Uyuşturucu vakasıyla kimi zaman bazı kişilerin gözaltına alındığı ve çeşitli operasyonların yapıldığı ya da yayalar üzerinde yapılan aramalarda uyuşturucu maddelere rastlanıldığı haberleri medyaya yansımıştır. ${ }^{1}$ Bunlar dışında yabancı uyrukluların yoğun olarak bulunduğu bu mahallede bir takım çatışmaların yaşandığı da ifade edilmiştir. $\mathrm{Bu}$ durum mahallenin genel ahengini bozarken, polislerin de sürekli uğrak mekânı olmuştur. Hatta polisin bir şüpheli aracı sokak aralarında takip ettiği de görülmüştür. Ayrıca mahallede sürekli devriye gezen polis ekipleri, sık sık Bağlar İlkokulu bahçesini ve parkları kontrol etmektedir. Bir defasında mahalle sakinleri bir uyuşturucu vakasında kendi evlerinin dahi arandığını ifade etmiş̧tir. Mahallenin genel peyzajını açıklayan bir katılımcı şu sözleri sarf etmiştir:

Birincisi izbe metruk ev çok fazla. Kısa süre önce bu evlerde uyușturucu alkol kullanımı yapılmaktaydı. Bu eski yerlere talep çok fazla. Talep eden aile yapıları da genellikle mülteci ve pek de toplum arasında yer bulamamış kişiler. İkincisi mahalle iskân ve imar açısından berbat. Birçok çıkmaz sokak var, her yer birbirine benziyor. Üçüncüsü çok fazla apart olması ve denetimin az olması sebebiyle yine bilindik suçlar.." (K9).

Suça ortam hazırlayan fiziki koşulların oluşu, suç işleyen ya da işlemeye meyilli bireylerin varlığ 1 veya suçun işlendiği bir yer olarak ifade edilen Bağlar Mahallesi, bu açıdan diğer yaşayanlar üzerinde bir takım olumsuzluklar üretmiştir. Çünkü yaşanılan çevrenin güvenliği kadınların bir suçun mağduru olabilme riskiyle ilişkili olabilmektedir. Özellikle yaşamın her aşamasında herhangi bir olaya maruz kalmaktan korkan kadınlar, yaşadıkları mekânlarda, sokaklarda veya okula ya da işe gidip gelirken çoğunlukla güvende olmayı istemektedir. Aynı şekilde kendi aile bireylerinin de doğal olarak güvende olmasını beklerler. Pain (1994), kadınların çocuklara verilen tehlikeli alanlarla ilgili uyarıların ve kısıtlamaların onları kamusal alanlardan uzaklaştırmaya yönelik tedbirlerden olduğunu belirtmiştir.

Aynı şekilde bazı durum ve zamanlarda sözlü ya da görsel tacize maruz kalmak, yabancı uyruklu bireylerle aynı mekânı paylaşmak veya meydana gelen bazı hırsızlık olaylarında herhangi bir saldırıya uğrama korkusuyla karşı karşıya kalmak kadınların da hareket özgürlüklerini sınırlandırmaktadır. Kadınları rahatsız eden bu tür davranışlar onların güvenliğini tehdit ederken, aynı zamanda mekânın sınırlı bir şekilde kullanıldığını göstermektedir. Pain (1997), bu korkunun sosyal inşasının böylece sosyo-cinsiyetli mekân bölünmesinde kendini gösterdiğini ifade etmektedir. Bu konuda Condon, vd., (2007) kadınların beyan ettikleri korkuların nedenlerinin, daha çok cinsiyete özgü şiddetle ilintili olduğunu vurgulamıştır. Ancak duyulan korkuya rağmen kadınlar dışarı çıkıp kaçınma stratejileri geliştirerek halka açık yerlerde baskın normlara karşı da direniş gösterdiğinin de altını çizmektedir.

Sonuç itibariyle suç kadar, sosyal ve psikolojik bir problem olan suç korkusu aslında her kesimi etkisi altına alabilecek bir konudur. Mahallenin suç veya suçluyu üreten bu özelliği bireyler üzerindeki hissedilen korkunun temel sebeplerini de oluşturmaktadır. Mahalledeki fiziki ve toplumsal düzensizlik ise bu korkunun kaynağı olarak gösterilebilir. Özellikle ev ortamında olduğu kadar kentsel alanlarda da duyulan korku, kadının her zaman bir tehlikeyle karşılaşabileceği kanısını doğurabilmektedir. Yaşanan bu güvensizlik, dolayısıyla bir korku kültürünün giderek daha fazla yaygın hale geldiğini ve çağımızın en önemli kaygılarından biri olduğunu vurgulamaktadır.

Hakem Değerlendirmesi: Dıș bağımsız.

Çıkar Çatışması: Yazarlar çıkar çatışması bildirmemiştir.

Finansal Destek: Yazarlar bu çalışma için finansal destek almadığını beyan etmiştir.

Peer-review: Externally peer-reviewed.

Conflict of Interest: The authors have no conflict of interest to declare.

Grant Support: The authors declared that this study has received no financial support.

\section{KAYNAKÇA/REFERENCES}

Ahmed, S. (2017). Duyguların kültürel politikası. Çev. Sultan Komut, 2. Bask1, Sel Yayınc1lk: İstanbul.

Balkin, S. (1979). Victimisation rates, safety and fear of crime. Social Problems, 26, 343-358.

Bernard, Y. (1992). North American and european research on fear of crime. Applied Psychology: An Internanonal Review, 41, 65-75.

Block, R. L. ve Block, C. R. (1995). Space, place and crime: hot spot areas and hot places of liquor related crime. Criminal Justice Press: USA.

Box, S., Hale, C. ve Andrews, C. (1988). Explaining fear of crime. The British Journal of Criminology, 28(3), 340-356.

Brantingham, P. L. ve Brantingham, P. J. (1995). Criminality of place: crime generators and crime attractors. European Journal on Criminal Policy and Research, 3, 5-26.

Bryman, A. (2007). Barriers to integrating quantitative and qualitative research. Journal of Mixed Methods Research, 1(1), 8-22.

Condon, S., Lieber, M., Maillochon, F. (2007). Feeling unsafe in public places: understanding women's fears. Revue Française de Sociologie, 5(48), 101-128. 
Covington, J. ve Taylor, R. B. (1991). Fear of crime in urban residential neighbourhoods: implications between-and within-neighbourhood sources for current models. The Sociological Quarterly, 32 (2), $231-249$

Demirel, G. (2017). Ötekinin korkusu: Haber bültenlerinde Türkiye'deki Suriyeliler. Akademik Sosyal Araştırmalar Dergisi, 5(60), 503-514.

Dobbs, R. R., Waid, C. A. ve Shelley, T. O. (2009). Explaining fear of crime as fear of rape among college females: an examination of multiple campuses in the united states. International Journal of Social Inquiry, 2(2), 105-122.

Eve, R. A. ve Eve, S. B. (1984). The effects of powerlessness, fear of social change and social integration on fear of crime among the elderly. Victimology, 9, 290-295.

Farrall, S., Bannister, J., Ditton, J. ve Gilchrist, E. (2000). Social psychology and the fear of crime: Re-examining a speculative model. The British Journal of Criminology, 40(3), 399-413.

Ferraro, K. F. ve LaGrange, R. (1987). The measurement of fear of crime. Sociological Review, 57, 70-101.

Ferraro, K. F. (1995). Fear of crime: Interpreting victimization risk. SUNY Press: New York.

Furedi, F. (2017). Korku kültürü: Risk almamanın riskleri. 3. Bask1, Çev. B. Yıldırım, Ayrıntı Yayınları: İstanbul.

Garofalo, J. (1981). The fear of crime: Causes and consequences. The Journal of Criminal Law and Criminology, 72(2), 839-857.

Gaster, G. (2001). On the nature of neighbourhood. Urban Studies, $38(12), 2111-2124$.

Gilchrist, E., Bannister, J., Ditton, J. ve Farral, S. (1998). Woman and the fear of crime, challenging the accepted stereotype. British Journal of Criminology, 38(2), 283-298.

Gökulu, G. (2018). Medya ve suç korkusu ilişkisi üzerine bir değerlendirme. Social Sciences Studies Journal (SSS Journal), 4(14), 585-594.

Hale, C. (1996). Fear of crime: A review of the literature. International Review of Victimology, 4, 79-150.

Harvey, D. (2009). Kapitalist kent. New Left Review, pp.181-202.

Harvey, D. (2016). Sosyal adalet ve şehir. Metis Yayınları: İstanbul.

Hilinski, C. M., Neeson, K.E.P. ve Andrews, H. (2011). Explaining the fear of crime among college women, in their own words. The Southwest Journal of Criminal Justice, 8(1), 112-127.

Hollway, W. ve Jefferson, T. (1997). The risk society in an age of anxiety: situating fear of crime. British Journal of Sociology, 48, $255-266$.

Irmak, F. ve Balkanlığlu, M.A. (2013). ABD'deki suç korkusunun sosyo-demografik analizi. Akademik Incelemeler Dergisi (Journal of Academic Inquiries), 8(3), 85-101.

Jackson, J. (2009). A Psychological perspective on vulnerability in the fear of crime. Psychology, Crime \& Law, 15(4), 365-390.

Jarrett-Luck, M. (2015). Reconceptualising fear of crime: the emergence of crime awareness. Doctoral Thesis, Criminology Department Faculty of Society and Design Bond University Queensland, Australia.
Koskela, H. (1999). Fear, control and space: Geographies of gender, fear of violence and video surveillance. University of Helsinki Press: Helsinki.

Kubrin, C. E. ve Weitzer, R. (2003). New directions in social disorganization theory. Journal of Research in Crime and Delinquency, 40(4), 374-402.

Kümbetoğlu, B. (2008). Sosyolojide ve Antropolojide niteliksel yöntem ve araştırma. 2. Baskı. Bağlam Yayıncılık: İstanbul.

Lee, T. (1968). Urban neighbourhood as a socio-spatial schema. Human Relations, 21(3), 241-267.

Lee, M. (2007). Inventing fear of crime: criminology and the politics of anxiety. Willan Publishing: Cullompton UK.

Meško, G., Fallshore, M., Muratbegović, E. ve Fields, C. (2008). Fear of crime in two post-socialist capital cities-Ljubljana, Slovenia and Sarajevo, Bosnia and Herzegovina. Journal of Criminal Justice, 36(6), 546-553.

Mogekwu, M. (2005). African union: Xenophobia as poor intercultural information. Ecquid Novi, 26(1), 5-20.

Pain, R. H. (1991). Space, sexual violence and social control: Integrating geographical and feminist analyses of women's fear of crime. Progress in Human Geography, 15(4), 415-431.

Pain, R. H. (1994). Kid gloves: children's geographies and the impact of violent crime. Occasional Paper New Series No. 1, Division of Geography and Environmental Management, University of Northumbria.

Pain R. H. (1997). Social geographies of women's fear of crime. Transactions of the Institute of British Geographers, 22(2), 231-244.

Pacione, M. (2003). Urban environmental quality and human wellbeing: a social geographical perspective. Landscape and Urban Planning, 65, 19-30.

Rader, N. (2017). Fear of Crime. Oxford Research Encyclopedia, Criminology and Criminal Justice. Oxford University Press: USA.

Rathzel, N. (2002). Developments in theories of racism. Europe's new racism: causes, manifestations and solution. Ellen Preckler ve The Evens Foundation (Edt.), içinde (s. 3-26). Oxford: Berghahn Books, New York.

Reid, L.W. ve Konrad, M. (2004). The gender gap in fear: assessing the interactive effects of gender and perceived risk on fear of crime. Sociological Spectrum, 24, 399-425.

Sipahi, E. B. (2016). Türkiye'de kent sakinlerinin suç korkuları üzerine bir araştırma. Uluslararası Sosyal Araştırmalar Dergisi, 9(43): 2158-2169.

Sipahi, E. B. (2017). Suç korkusu Türkiye kentlerinde bir alan araştırması. Çizgi Kitabevi: Konya

Soja, E. W. (1980). The socio-spatial dialectic. Annals of the Association of American Geographers, 70(2), 207-225.

Stanko, E. (1990). Everyday violence: how woman and men experience sexual and physical danger, Pandora: Londra.

Temurçin, K. (2018). Suç Coğrafyası: Göreli kavramsallaştırmadan mekânsal yorumlamaya. Edt. Nurettin Özgen, Sosyal Coğrafya. Pegem Akademi Yayınları: Ankara s.419-448. 
Tandoğan, O. ve İlhan, B. Ş. (2016). Fear of crime in public spaces: From the view of women living in cities. Procedia Engineering, 161, 2011-2018.

Valentine, G. (1989). The geography of women's fear. Area, 21(4), 385390.

Valentine, G. (1990). Women's fear and the design of public space. Built Environment, 16(4), 288-303.

Warr, M. (2000). Fear of crime in the United States: Avenues for research and Policy. Measurement and Analysis of Crime and Justice, 4, 451-489.
Warr, M. ve Ellison, C. G. (2000). Rethinking social reactions to crime: personal and altruistic fear in family households. American Journal of Sociology, 106(3), 551-578.

Yıldırım, A. ve Şimşek, H. (2013). Sosyal bilimlerde nitel araştırma yöntemleri, 9. Baskı. Seçkin Yayıncılık: Ankara.

\section{Diğer Kaynaklar}

Isparta Belediyesi İmar Müdürlüğü (2018).

Isparta İl Emniyet Müdürlüğü (2018). Isparta Merkez Mahalleleri Suç İstatistikleri.

http://www.bomba32.com/haber/isparta/baglar-mahallesinde-yakayieleverdiler/28486.html (S.E.T.: 05.02.2020) 